CyTA - Journal of Food

\title{
Technical and economical evaluation of microbial transglutaminase production on enzymatic hydrolysates of potato (Solanum tuberosum)
}

\section{Esther Guerra-Rodríguez \& Manuel Vázquez}

To cite this article: Esther Guerra-Rodríguez \& Manuel Vázquez (2013) Technical and economical evaluation of microbial transglutaminase production on enzymatic hydrolysates of potato (Solanum tuberosum), CyTA - Journal of Food, 11:3, 277-284, DOI: 10.1080/19476337.2012.736414

To link to this article: https://doi.org/10.1080/19476337.2012.736414

\section{Copyright Taylor and Francis Group, LLC}

\section{Published online: 14 Feb 2013.}

Submit your article to this journal ¿

Џلll Article views: 529

Q View related articles $₫$

Citing articles: 6 View citing articles $๘$ 


\title{
Technical and economical evaluation of microbial transglutaminase production on enzymatic hydrolysates of potato (Solanum tuberosum)
}

\section{Evaluación técnica y económica de la producción de transglutaminasa microbiana en hidrolizados enzimáticos de patata (Solanum tuberosum)}

\author{
Esther Guerra-Rodríguez and Manuel Vázquez* \\ Food Technology Area, Department of Analytical Chemistry, Faculty of Veterinary Science, University of Santiago de Compostela \\ (Campus Lugo), 27002 Lugo, Spain
}

(Received 17 July 2012; final version received 30 September 2012)

\begin{abstract}
New low-cost culture media for microbial transglutaminase production are desired to enhance the economics of its biotechnological production. The aim of this work was to evaluate the production of transglutaminase from enzymatic hydrolysates of potato by Streptomyces mobaraensis in a reduced nutritional medium. An experimental design was performed to optimise the composition of yeast extract (YE), corn steep liquor (CSL) and sodium caseinate (SC) as nutritional supplements. The results showed a significant effect of YE and SC, the effect of CSL being non-significant. Economic yield was also modelled for evaluating the economics of the process. Optimal conditions selected were $10 \mathrm{~g} / \mathrm{L}$ of $\mathrm{YE}, 2 \mathrm{~g} / \mathrm{L}$ of CSL and $13.7 \mathrm{~g} / \mathrm{L}$ of SC, yielding a maximum activity of $1.128 \pm 0.100 \mathrm{U} / \mathrm{mL}$ and a transglutaminase economic yield of $3.72 €$ per $€$ spent in nutrients. The results showed that enzymatic hydrolysates of potato were feasible media for the production of transglutaminase.
\end{abstract}

Keywords: potato; transglutaminase; Streptomyces mobaraensis; Solanum tuberosum

\begin{abstract}
Se necesitan nuevos medios de cultivo de bajo coste para la producción de transglutaminasa microbiana para mejorar la economía de su producción biotecnológico. Estos medios de cultivo contienen una fuente de carbono, que puede ser obtenido de la patata (Solanum tuberosum), una abundante fuente de almidón. El almidón de patata se puede transformar en glucosa mediante hidrólisis enzimática. El objetivo de este trabajo fue evaluar la producción de transglutaminasa a partir de hidrolizados enzimáticos de patata por Streptomyces mobaraensis en un medio nutritivo reducida. Se realizó un diseño experimental para optimizar la composición de extracto de levadura (YE), licor de maceración de maíz (CSL) y caseinato sódico (SC) como suplementos nutricionales. Los resultados mostraron un efecto significativo de YE y SC, siendo el efecto de CSL no significativa. También se modeló el rendimiento económico para evaluar la economía del proceso. Las condiciones óptimas seleccionadas fueron: $10 \mathrm{~g} / \mathrm{L} \mathrm{de} \mathrm{YE,} 2 \mathrm{~g} / \mathrm{L}$ de CSL y 13,7 $\mathrm{g} / \mathrm{L}$ de SC, produciendo una actividad máxima de $1,128 \pm 0,100 \mathrm{U} / \mathrm{ml}$ y un rendimiento económico de transglutaminasa de $3,72 €$ por $€$ gastado en nutrientes. Los resultados mostraron que los hidrolizados enzimáticos de patata fueron medios viables para la producción de transglutaminasa.
\end{abstract}

Palabras claves: patata; transglutaminasa; Streptomyces mobaraensis; Solanum tuberosum

\section{Introduction}

Transglutaminase (protein-glutamine gamma-glutamyltransferase, EC 2.3.2.13) is a family of enzymes that have been evolved for the cross-linking of proteins (Sommer, Volk, \& Pietzsch, 2011). Transglutaminase has been found in animals, plants and microorganisms (Beninati \& Piacentini, 2004). Transglutaminase from animals have been classified into at least five types, such as plasma, tissue, keratinocyte, epidermis and pro-state types, and are involved in various biological processes (blood clotting, wound healing, keratinisation of epidermis, apoptosis, cell differentiation and cell signalling).

Microbial transglutaminase (MTG) has acquired interest due to its application in the food industries (Yan, Du, Li, Chen, \& Zhong, 2005; Zhou, Chen, \& Du, 2000). The MTG is used in food technology to restructure protein foods such as meat, dairy and fish products. Furthermore, stability, water binding, mechanical and textural properties can be enhanced (Bonato, Perlo, Teira, Fabre, \& Kueider, 2006; Castro-
Briones et al., 2009; Ramirez, Uresti, Tellez, \& Vazquez, 2002; Tellez-Luis, Uresti, Ramirez, \& Vazquez, 2002; Uresti, Velazquez, Ramirez, Vazquez, \& Torres, 2004). The increasing demand for vegetarian food and the utilisation of novel proteins as functional ingredients from soy, peas, sesame and sunflower open new horizons for transglutaminase applications (Dube, Schaefer, Neidhart, \& Carle, 2007).

From the industrial perspective, the enzyme can be obtained from Streptomyces mobaraensis (Nagy \& Szakacs, 2008). The composition of the media used to produce MTG from Streptomyces species has been almost the same in all works published since Ando, Adachi, Umeda, Matsuura, and Nonaka (1989). In contrast, in biotechnologically based industrial processes, the formulation of the culture media is of critical importance, because the composition affects product concentration, yield and volumetric productivity (Bahrim, Iancu, Butu, \& Negoita, 2010; Portilla-Rivera, Tellez-Luis, \& Vazquez, 2009; Tellez-Luis, Ramirez, \& Vazquez, 2004).

*Corresponding author. Email: manuel.vazquezm@usc.es 
Fermentation media can represent almost $30 \%$ of the cost for a microbial production (Portilla-Rivera et al., 2009). General media employed for the growth of Streptomyces are not economically attractive. Cheaper media based on wastes from the agro-industry have been studied for the production of transglutaminase. For example, the transglutaminase production on hydrolysates of sorghum straw (Tellez-Luis, Gonzalez Cabriales, Ramirez, \& Vazquez, 2004) and sugar cane molasses (Portilla-Rivera et al., 2009) was studied. Glycerol (1,2,3-propanetriol or glycerine) alone as carbon source was also studied for the production of MTG (TellezLuis et al., 2004).

It is of interest to find alternative raw materials of low cost for preparing fermentation media. Non-commercial potatoes (Solanum tuberosum) have a cost lower than $0.1 €$ per kg (Montouto-Grana, Vazquez-Oderiz, Romero-Rodriguez, \& Munoz-Ferreiro, 2012; Vazquez, Delgado, \& Castro, 2009). These are agricultural wastes that can be hydrolysed to be used as media for the microbial production of transglutaminase.

A hydrolysis step is required when microorganisms are not able to produce extracellular hydrolysing starch enzymes. Starch hydrolysis products such as glucose syrup are typically based on acid or enzymatic hydrolysis. Both hydrolyses can lead to the production of glucose solutions, which can be fermented to produce MTG.

The main drawback of acid hydrolysis is the generation of degradation products such as furfural, 5-(hydroxymethyl)2 -furaldehyde (HMF) and acetic acid that remain in the glucose solutions. These by-products are microbial growth inhibitors and must be controlled under lethal concentrations to allow posterior fermentations (Guerra-Rodriguez, Portilla-Rivera, Jarquin-Enriquez, Ramirez, \& Vazquez, 2012; Wang, Yu, \& Wei, 2012; Zeni et al., 2011).

Enzyme hydrolysis has the advantage that generates glucose solutions that can be fermented without further treatments. No microbial growth inhibitors exist in the enzyme hydrolysis (Delgado, Castro, \& Vazquez, 2009; Vazquez et al., 2009).

The potato hydrolysate is a carbon source for microbial growth, but it needs the supplementation with other nutrients that provide nitrogen and micronutrients. Yeast extract or peptone is frequently used but the cost is high (Bustos, Moldes, Alonso, \& Vazquez, 2004; Tellez-Luis, Moldes, Vazquez, \& Alonso, 2003). Caseinate has been reported as inductor of the production of MTG (Junqua, Duran, Gancet, \& Goulas, 1997; Tellez-Luis et al., 2004; Yan et al., 2005). Corn steep liquor was never used in the production of transglutaminase, but this is a cheap nutrient that has been tested satisfactorily for other fermentations such as lactic acid production (Bustos et al., 2004; Ce, Norena, \& Brandelli, 2012; Tellez-Luis et al., 2003; Zidani, Fahloul, \& Bacha, 2012).

There are no studies about the use of enzymatic potato hydrolysates for the production of MTG. In this study, a low-cost nutrient medium based on enzymatic potato hydrolysates supplemented with yeast extract (YE), corn steep liquor (CSL) and sodium caseinate (SC) was developed for MTG production. The effect of the media composition was modelled and the production of transglutaminase by Streptomyces mobaraensis optimised. Economic yield was also modelled for evaluating the economics of the process.

\section{Materials and methods}

\section{Raw potatoes processing and microorganism}

Potatoes supplied by local farmers (Dozón, Spain) were washed, sliced, dried and ground to be used in this work. The water extracted from potatoes was $80.35 \%$ of the fresh weight. The dried potatoes contained residual $8.13 \%$ moisture.

The enzymes used in this study were commercial $\alpha$ amylase (Termamyl SC DS ${ }^{\circledR}$, Novo Nordisk, Denmark) and glucoamylase $\left(\right.$ Sacyme ${ }^{\mathbb{R}}$, Novo Nordisk, Denmark). The conditions of the enzymatic hydrolysis to obtain potato hydrolysates have been previously described (Delgado et al., 2009; Vazquez et al., 2009).

The microorganism employed in this work was S. mobaraensis CECT 3230 obtained from the Spanish Collection of Type Cultures (http://www.cect.org/). The fermentation experiments were carried out in orbital shakers at $26^{\circ} \mathrm{C}, 250 \mathrm{RPM}$ allowing a fermentation time of $96 \mathrm{~h}$.

The experiments were carried out in a $250-\mathrm{mL}$ Erlenmeyer flask with a final volume of $100 \mathrm{~mL}$ by employing different media based on potato hydrolysates supplemented with YE, CSL and SC as described in the result and discussion section.

\section{Analytical methods}

Samples were withdrawn at given times. They were centrifuged for $15 \mathrm{~min}$ at $10,000 \mathrm{~g}$ at room temperature. The supernatant was used for sugar determination by HPLC and transglutaminase activity determination. Pellets were washed twice with a solution of $9 \mathrm{~g} / \mathrm{L}$ of sodium chloride in deionised water, centrifuged again and then dried at $102^{\circ} \mathrm{C}$ for $48 \mathrm{~h}$, in order to allow the calculation of the biomass concentration on dry weight basis.

Glucose released by the hydrolysis and consumed during fermentation was measured by HPLC using a Rezex RHM (Phenomenex, Torrance, California, USA) column with isocratic elution (flow rate of $0.400 \mathrm{~mL} / \mathrm{min}$ and mobile phase of $0.025 \mathrm{M} \mathrm{H}_{2} \mathrm{SO}_{4}$ ), a column oven set at $45^{\circ} \mathrm{C}$ and a refractive index detector (LC 2000 plus, Jasco, Tokio, Japan).

Transglutaminase activity was determined with colorimetric procedure described by Grossowicz, Wainfan, Borek, and Waelsch (1950). $N$ - $\alpha$-CBZ-gln-gly (Sigma-Aldrich Corp, St. Louis, MO, USA) was used as a substrate. A calibration curve was made using L-glutamic acid $\gamma$-monohydroxamate (Sigma). One unit of activity (U) was defined as the amount that causes the formation of $1 \mu \mathrm{mol}$ of hydroxamate in $1 \mathrm{~min}$ at $37^{\circ} \mathrm{C}$.

\section{Modelling and statistical methods}

The set of experiments followed a second-order, incomplete, factorial structure. The yeast extract, corn steep liquor and sodium caseinate were considered as operational variables (denoted YE, CSL and SC, respectively) and their effects on the selected dependent variable (transglutaminase activity for $96 \mathrm{~h})$ were calculated. For computation purposes, the normalised, dimensionless variables $x_{1}, x_{2}, x_{3}$ were defined as:

$$
\begin{gathered}
X_{1}=\frac{\mathrm{YE}-6}{4} \\
X_{2}=\frac{\mathrm{CSL}-15}{15} \\
X_{3}=\frac{\mathrm{SC}-6}{4}
\end{gathered}
$$


The set of experiments followed the Box-Behnken design (Box \& Behnken, 1960). This design is formed by combining two-level factorial designs with incomplete block designs. This procedure creates designs with desirable statistical properties but with only a fraction of the experiments required for a three-level factorial design.

Table 1 summarises the variables involved in the experimental design for the production of transglutaminase. The values of fixed variables (agitation, temperature, mineral concentrations, ratio activity units/substrate and the fraction of $\alpha$-amylase/total enzymes) were selected on the basis of previous studies (Delgado et al., 2009; Portilla-Rivera et al., 2009; Vazquez et al., 2009).

The experiment design was statistically analysed using the Design Expert ${ }^{\mathbb{R}}$ 7.1.1 software (Stat-Ease, Inc., Minneapolis, Minnesota, USA). The model was validated through analysis of variance (ANOVA) test.

\section{Results}

\section{Overall process}

The overall process of this work is shown in Figure 1. Briefly, the potatoes were washed, sliced and then dried at $60^{\circ} \mathrm{C}$. The residual moisture was $8.13 \%$. The dried potatoes were ground and treated at $100^{\circ} \mathrm{C}$ with agitation until boiling, forming a gel. Then, it was mixed with a buffer solution to reach $\mathrm{pH} 5$, and diluted enzyme solution was added to start the hydrolysis reaction. At end of the reaction, the hydrolysate was filtered and the liquid is the glucose solution containing about $18 \mathrm{~g} / \mathrm{L}$ that was used as substrate for the growth of $S$. mobaraensis for the production of

Table 1. Variables involved in the experiments design (BoxBehnken) for the production of transglutaminase.

Tabla 1. Variables involucradas en el diseño experimentañ (BoxBehnken) para la producción de transglutaminasa.

\begin{tabular}{|c|c|c|c|}
\hline & Nomenclature & Units & $\begin{array}{l}\text { Variation } \\
\text { levels }\end{array}$ \\
\hline \multicolumn{4}{|l|}{ (a) Fixed variables } \\
\hline Agitation & $A$ & $\mathrm{rpm}$ & 250 \\
\hline Temperature & $T$ & ${ }^{\circ} \mathrm{C}$ & 26 \\
\hline \multicolumn{4}{|l|}{ (b) Fixed composition } \\
\hline $\begin{array}{l}\text { Dibasic sodium } \\
\text { phosphate }\end{array}$ & & $\mathrm{g} / \mathrm{L}$ & 5 \\
\hline $\begin{array}{l}\text { Monobasic potassium } \\
\text { phosphate }\end{array}$ & & $\mathrm{g} / \mathrm{L}$ & 2 \\
\hline Magnesium sulphate & & $\mathrm{g} / \mathrm{L}$ & 0.5 \\
\hline Ratio enzyme/substrate & & $\mathrm{U} / \mathrm{g}$ & 6 \\
\hline \multicolumn{4}{|l|}{ Fraction of activity } \\
\hline$\alpha$-amylase/total enzymes & & $\begin{array}{c}\mathrm{U} / \text { total } \\
\mathrm{U}\end{array}$ & 0.35 \\
\hline \multicolumn{4}{|c|}{ (c) Independent variables (factors) } \\
\hline Yeast extract & YE & $\mathrm{g} / \mathrm{L}$ & $(2,6,10)$ \\
\hline Corn steep liquor & CSL & $\mathrm{g} / \mathrm{L}$ & $(2,6,10)$ \\
\hline Sodium caseinate & $\mathrm{SC}$ & $\mathrm{g} / \mathrm{L}$ & $(0,15,30)$ \\
\hline \multicolumn{4}{|l|}{$\begin{array}{c}\text { (d) Dimensionless, normalised } \\
\text { independent variables }\end{array}$} \\
\hline Yeast extract & $x_{1}$ & $\mathrm{~g} / \mathrm{L}$ & $(-1,0,1)$ \\
\hline Corn steep liquor & $x_{2}$ & $\mathrm{~g} / \mathrm{L}$ & $(-1,0,1)$ \\
\hline Sodium caseinate & $x_{3}$ & $\mathrm{~g} / \mathrm{L}$ & $(-1,0,1)$ \\
\hline \multicolumn{4}{|c|}{ (e) Dependent variable (response) } \\
\hline $\begin{array}{r}\text { Transglutaminase } \\
\text { activity for } 96 \mathrm{~h}\end{array}$ & $\mathrm{TG}_{96}$ & $\mathrm{U} / \mathrm{mL}$ & \\
\hline
\end{tabular}

transglutaminase. Hydrolysates were supplemented with nutrients, sterilised and inoculated with $S$. mobaraensis. The fermentations were stopped at $96 \mathrm{~h}$, and the biomass was separated by centrifugation. The liquid was the enzymatic crude extract containing microbial transglutaminase.

Experiments were performed to optimise the composition of nutrients that allow the highest transglutaminase activity obtained in the crude extracts and models were obtained.

\section{Mathematical modelling}

The nutrient composition used for the supplementation of the potato hydrolysates (in terms of dimensional and dimensionless operational variables) as well as the experimental results obtained at $96 \mathrm{~h}$ of fermentation are shown in Table 2 . The interrelationship between nutrient composition variables can be established through an equation including linear, interaction and second-order terms. The mathematical model used as first approach was a polynomial model of quadratic order as shown in Equation (4):

$$
\mathrm{TGh}=a_{0}+\sum_{i} a_{i} x_{i}+\sum_{i} b_{i} x_{i}^{2}+\sum_{i} \sum_{j} c_{i j} x_{i} x_{j}
$$

where TGh is transglutaminase activity obtained after $\mathrm{h}$ hours of fermentation; $x_{i}$ are the normalised dimensionless variables $\left(x_{1}, x_{2}, x_{3}\right)$ and $a_{0}, a_{i}, b_{i}, c_{i j}$ are regression coefficients calculated fitting the experimental data by multiple regression. Partial models of the quadratic model were also fitted.

The results of transglutaminase activity at $96 \mathrm{~h}\left(\mathrm{TG}_{96}\right)$ were in the range from 0.030 to $1.234 \mathrm{U} / \mathrm{mL}$. This implies maximum/minimum ratio values of 41.13 . A ratio higher than 10 generally indicates the need for a data transformation.

The Box-Cox method is a tool that helps to determine the transform of the power most appropriate to apply to the data of the response variable, in this case $\mathrm{TG}_{96}$.

The lowest value in the Box-Cox plot represents the value of lambda $(\lambda)$ resulting from the minimum residual sum of squares in the transformed model. The possibility of applying a data transformation is greater when the ratio maximum/minimum value of the response data is greater than 3. Power transformations can be performed only on the responses that are greater than zero. Figure 2 shows the result of the Box-Cox data for $\mathrm{TG}_{96}$. The figure shows the BoxCox minimum values of lambda $(\lambda)$ and the $\lambda$ to a confidence level of $95 \%$.

The Box-Cox analysis recommends using a 0.5 lambda. Therefore, it recommends $\mathrm{TG}_{96}$ transform data by the square root. This transformation was performed before the model fit the data.

Table 3 shows the sum of squares for the partial and complete models. Data fitted well to a quadratic model due to the lowest $p$-value (0.0019) calculated. Therefore, the mathematical quadratic model for $\mathrm{TG}_{96}$ as function of the normalised variables was selected as follows:

$$
\begin{aligned}
\sqrt{\mathrm{TG}_{96}}= & a_{0}+a_{1} x_{1}+a_{2} x_{2}+a_{3} x_{3}+c_{1} x_{1} x_{2}+c_{2} x_{1} x_{3} \\
& +c_{3} x_{2} x_{3}+b_{1} x_{1}^{2}+b_{2} x_{2}^{2}+b_{3} x_{3}^{3}
\end{aligned}
$$

Table 4 shows the coefficients calculated by ANOVA. The $F$ value of 46.25 implies that the model was significant. There is 


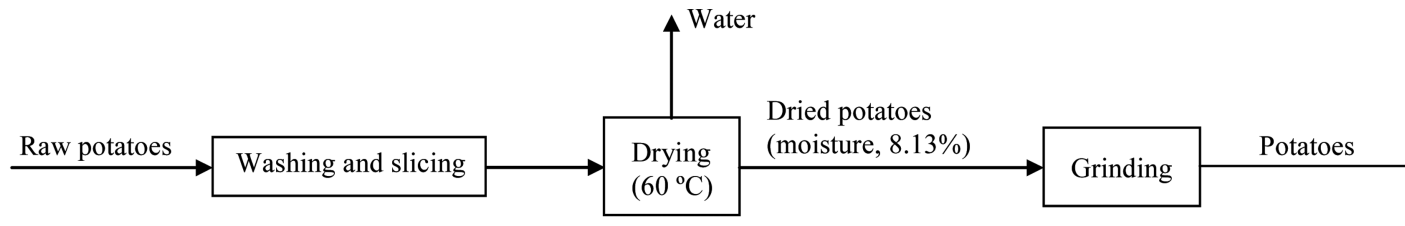

Diluted 1:55000 commercial $\alpha$-amylase (Termamyl SC DS)

Diluted 1:7500 commercial

Glucoamylase (Saczyme)

Citric acid $0.15 \mathrm{M}-\mathrm{Na}_{2} \mathrm{HPO}_{4} 0.3 \mathrm{M}$ Buffer pH 5

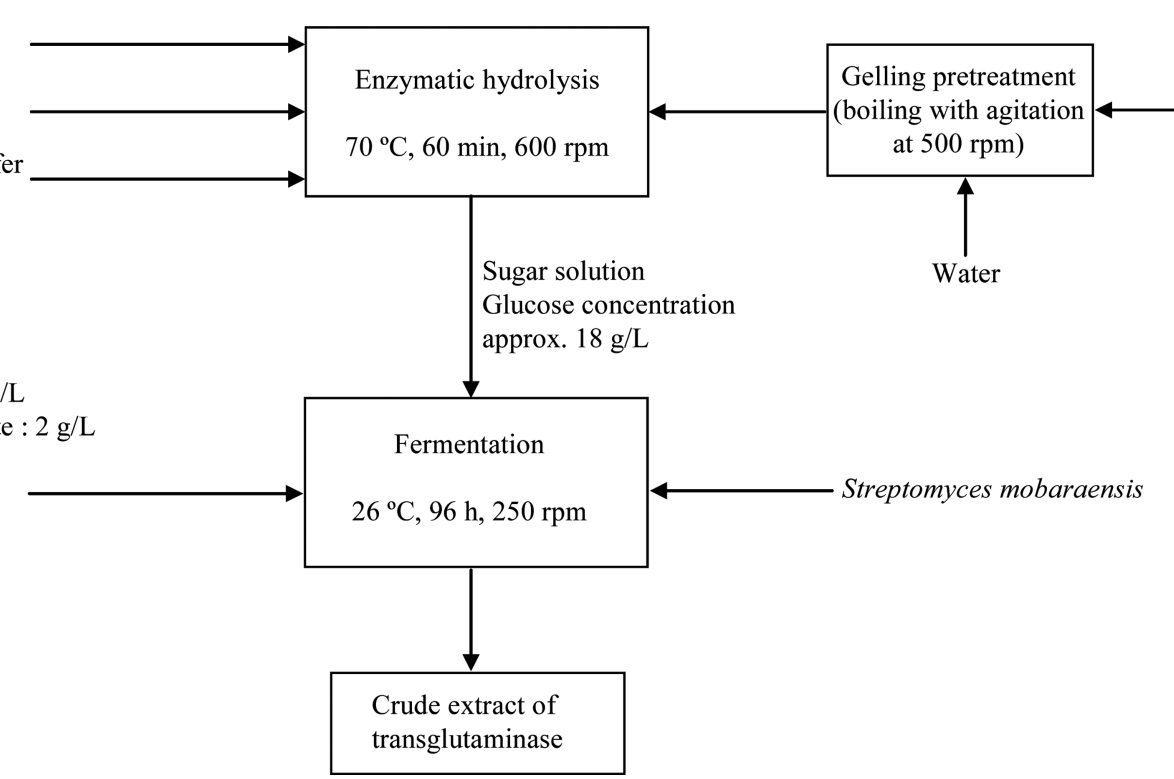

Figure 1. Overall process proposed for the production of transglutaminase using enzymatic hydrolysis of potato.

Figura 1. Proceso global propuesto para la producción de transglutaminasa usando hidrolizados enzimáticos de patata.

Table 2. Design of experiments and results of transglutaminase activity obtained at $96 \mathrm{~h}$ of fermentation.

Tabla 2. Diseño de experimentos y resultados de actividad transglutaminásica obtenidas en 96 h de fermentación.

\begin{tabular}{|c|c|c|c|c|c|c|c|}
\hline \multirow[b]{3}{*}{ Experiment } & \multicolumn{6}{|c|}{ Independent variables } & \multirow{3}{*}{$\begin{array}{c}\begin{array}{c}\text { Dependent } \\
\text { variable }\end{array} \\
\\
\mathrm{TG}_{96} \\
(\mathrm{U} / \mathrm{mL})\end{array}$} \\
\hline & \multicolumn{3}{|c|}{$\begin{array}{l}\text { Dimensional } \\
\quad(\mathrm{g} / \mathrm{L})\end{array}$} & \multicolumn{3}{|c|}{ Dimensionless } & \\
\hline & $\mathrm{YE}$ & CSL & $\mathrm{SC}$ & $x_{1}$ & $x_{2}$ & $x_{3}$ & \\
\hline 1 & 6.0 & 2.0 & 30.0 & 0 & -1 & 1 & 1.037 \\
\hline 2 & 2.0 & 6.0 & 30.0 & -1 & 0 & 1 & 1.187 \\
\hline 3 & 10.0 & 10.0 & 15.0 & 1 & 1 & 0 & 1.207 \\
\hline 4 & 10.0 & 6.0 & 30.0 & 1 & 0 & 1 & 1.174 \\
\hline 5 & 10.0 & 6.0 & 0.0 & 1 & 0 & -1 & 0.334 \\
\hline 6 & 2.0 & 10.0 & 15.0 & -1 & 1 & 0 & 0.726 \\
\hline 7 & 6.0 & 6.0 & 15.0 & 0 & 0 & 0 & 1.121 \\
\hline 8 & 6.0 & 6.0 & 15.0 & 0 & 0 & 0 & 0.928 \\
\hline 9 & 10.0 & 2.0 & 15.0 & 1 & -1 & 0 & 1.234 \\
\hline 10 & 2.0 & 6.0 & 0.0 & -1 & 0 & -1 & 0.030 \\
\hline 11 & 6.0 & 10.0 & 0.0 & 0 & 1 & -1 & 0.144 \\
\hline 12 & 6.0 & 2.0 & 0.0 & 0 & -1 & -1 & 0.169 \\
\hline 13 & 2.0 & 2.0 & 15.0 & -1 & -1 & 0 & 0.575 \\
\hline 14 & 6.0 & 6.0 & 15.0 & 0 & 0 & 0 & 0.916 \\
\hline 15 & 6.0 & 10.0 & 30.0 & 0 & 1 & 1 & 1.075 \\
\hline
\end{tabular}

only a $0.03 \%$ chance that this large "Model $F$-value" could occur due to noise. The value of " $p$-value probability $>F$ " was lower than 0.0003 . The values of "prob $>F$ " less than 0.0500 indicate that the model terms $x_{1}, x_{3}, x_{1} \cdot x_{3}$ and $x_{3}^{2}$ were significant. But the terms $x_{2}, x_{1} \cdot x_{2}, x_{2} \cdot x_{3}, x_{1}^{2}$ and $x_{2}^{2}$ were not significant and can be deleted to improve the

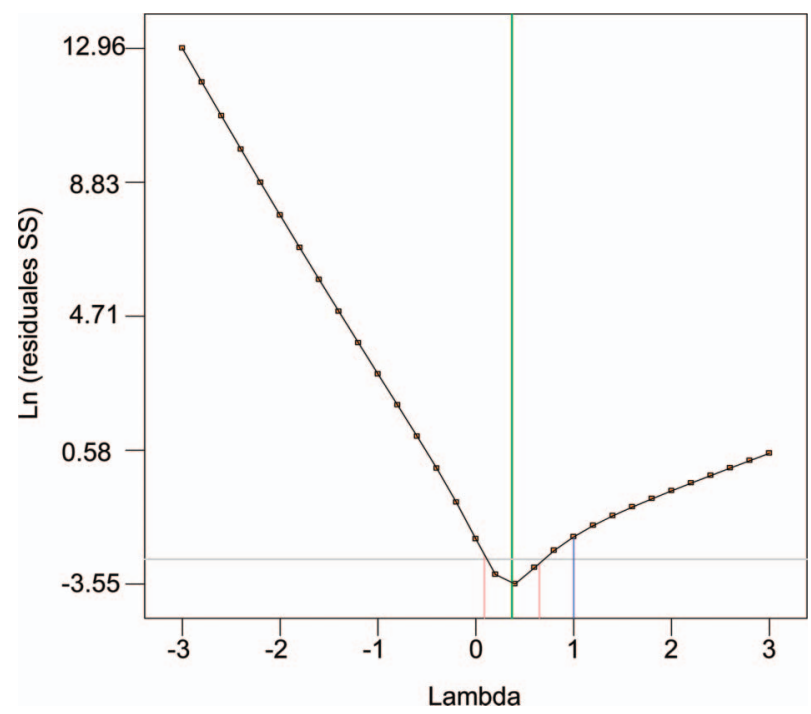

Figure 2. Box-Cox plot for the power transformation.

Figura 2. Gráfica de Box-Cox para la transformación de la potencia.

robustness of the model. Therefore, a new fitting was performed for the reduced model showed in Equation (6).

$$
\sqrt{\mathrm{TG}_{96}}=a_{0}+a_{1} x_{1}+a_{3} x_{3}+c_{2} x_{1} x_{3}+b_{3} x_{3}^{2}
$$

Table 5 shows the coefficients recalculated by ANOVA for the Equation (6). The $F$-value increased up to 141.49 . The 
Table 3. Summary of the sequential model of squares.

Tabla 3. Resumen de los modelos secuenciales cuadráticos.

\begin{tabular}{lccrr}
\hline Source & Sum of squares & df & Mean square & $F$-value \\
\hline Mean vs. Total & 10.53 & 1 & 10.53 & 0.34 \\
Linear vs. Mean & 1.03 & 3 & 0.015 & 12.64 \\
2FI vs. Linear & 0.046 & 3 & 0.079 & 0.48 \\
Quadratic vs. 2FI & 0.24 & 3 & $3.078 \mathrm{E}-003$ & 0.0007 \\
Cubic vs. Quadratic & $9.234 \mathrm{E}-003$ & 3 & $3.248 \mathrm{E}-003$ & 0.95 \\
Residual & $6.497 \mathrm{E}-003$ & 2 & 0.79 & 0.0019 \\
Total & 11.86 & 15 & 0.5503 \\
\hline
\end{tabular}

Table 4. Analysis of variance (ANOVA) for the quadratic model.

Tabla 4. Análisis de varianza (ANOVA) para el modelo cuadrático.

\begin{tabular}{llllrr}
\hline Source & $\begin{array}{l}\text { Sum of } \\
\text { squares }\end{array}$ & df & Mean square & $F$-value & $\begin{array}{c}p \text {-value } \\
\text { probability } \\
>F\end{array}$ \\
\hline Model & 1.31 & 9 & 0.15 & 46.25 & 0.0003 \\
$x_{1}$ (YE) & 0.12 & 1 & 0.12 & 39.56 & 0.0015 \\
$x_{2}$ (CSL) & $5.851 \mathrm{E}-004$ & 1 & $5.851 \mathrm{E}-004$ & 0.19 & 0.6842 \\
$x_{3}$ (SC) & 0.90 & 1 & 0.90 & 286.75 & $<0.0001$ \\
$x_{1} \cdot x_{2}$ & $2.808 \mathrm{E}-003$ & 1 & $2.808 \mathrm{E}-003$ & 0.89 & 0.3881 \\
$x_{1} \cdot x_{3}$ & 0.042 & 1 & 0.042 & 13.40 & 0.0146 \\
$x_{2} \cdot x_{3}$ & $6.278 \mathrm{E}-004$ & 1 & $6.278 \mathrm{E}-004$ & 0.20 & 0.6738 \\
$x_{1}^{2}$ & $3.158 \mathrm{E}-004$ & 1 & $3.158 \mathrm{E}-004$ & 0.10 & 0.7642 \\
$x_{2}^{2}$ & $3.074 \mathrm{E}-003$ & 1 & $3.074 \mathrm{E}-003$ & 0.98 & 0.3683 \\
$x_{3}^{2}$ & 0.24 & 1 & 0.24 & 74.99 & 0.0003 \\
Residual & 0.016 & 5 & $3.146 \mathrm{E}-003$ & & \\
Lack of fit & $9.234 \mathrm{E}-003$ & 3 & $3.078 \mathrm{E}-003$ & 0.95 & 0.5503 \\
Pure error & $6.497 \mathrm{E}-003$ & 2 & $3.248 \mathrm{E}-003$ & & \\
\hline
\end{tabular}

Table 5. Analysis of variance (ANOVA) for reduced quadratic model deleting the non-significant terms.

Tabla 5. Análisis de varianza (ANOVA) para el modelo cuadrático reducido eliminando los términos no significativos.

\begin{tabular}{llrlrr}
\hline Source & $\begin{array}{l}\text { Sum of } \\
\text { squares }\end{array}$ & df & $\begin{array}{c}\text { Mean } \\
\text { square }\end{array}$ & $F$-value & $\begin{array}{c}p \text {-value } \\
\text { probability } \\
>F\end{array}$ \\
\hline Model & 1.30 & 4 & 0.33 & 141.49 & $<0.0001$ \\
$x_{1}$ (YE) & 0.12 & 1 & 0.12 & 54.10 & $<0.0001$ \\
$x_{3}$ (SC) & 0.90 & 1 & 0.90 & 392.08 & $<0.0001$ \\
$x_{1} \cdot x_{3}$ & 0.042 & 1 & 0.042 & 18.33 & 0.0016 \\
$x_{3}^{2}$ & 0.23 & 1 & 0.23 & 101.45 & $<0.0001$ \\
Residual & 0.023 & 10 & $2.301 \mathrm{E}-003$ & & \\
Lack of fit & 0.017 & 8 & $2.064 \mathrm{E}-003$ & 0.64 & 0.7348 \\
Pure error & $6.497 \mathrm{E}-003$ & 2 & $3.248 \mathrm{E}-003$ & & \\
\hline
\end{tabular}

value of " $p$-value probability $>F$ " was also lower than 0.0001 . The "lack of fit $F$-value" of 0.64 implies that the lack of fit is not significant relative to the pure error (nonsignificant lack of fit is good).

The value of $r^{2}$ is 0.9826 . This statistical parameter is usually utilised to determine the correlation of a model. However, it is better to compare the values of "adjusted $r^{2}$ ", and "predicted $r^{2}$ ". Parameter "adjusted $r^{2}$ " is a measure of the amount of variation around the mean explained by the model, adjusted for the number of terms in the model. The "adjusted $r^{2}$ " decreases as the number of terms in the model increases if those additional terms do not add value to the model. The "predicted $r^{2}$ " is a measure of the amount of variation in new data explained by the model. The "predicted $r^{2}$ " obtained (0.9532) is in reasonable agreement with the "adjusted $r^{2}$ " obtained (0.9757). The predicted $r^{2}$ and the adjusted $r^{2}$ should be within 0.20 of each other. Otherwise, there may be a problem with either the data or the model. Another statistical parameter used to evaluate the significances of a model is "Adequate precision". This measures the signal/noise ratio. A ratio greater than 4 is desirable. The ratio obtained (33.87) indicates an adequate signal. All these statistical parameters confirm that the empirical Equation (7) obtained can be used to model the production of transglutaminase in enzymatic hydrolysates of potato supplemented with the nutrients studied.

$$
\sqrt{\mathrm{TG}_{96}}=0.97+0.12 x_{1}+0.34 x_{3}-0.10 x_{1} x_{3}-0.25 x_{3}^{2}
$$

The evaluation of the coefficients obtained shows that the transglutaminase production is mainly affected by the concentration of SC in the potato hydrolysates, followed by the concentration of YE. An interaction between YE and SC was determined. CSL was not significant in the range of study. A quadratic effect of SC was also observed. The equation for the decoded variable is:

$$
\begin{aligned}
\sqrt{\mathrm{TG}_{96}}= & 0.044+0.056 \mathrm{YE}+0.0659 \mathrm{SC}-1.711 \mathrm{YE} \cdot \mathrm{SC} \\
& -1.111 \mathrm{SC}^{2}
\end{aligned}
$$

Figure 3 shows the predicted vs. experimental values of production of transglutaminase. Groups of points above or below the line could indicate areas of over or under prediction. It can be observed that the points were randomly scattered along the 45-degree line. To evaluate the strength of the model, a residual test was also performed.

The response surface of the model is shown in Figure 4. In this figure, the effect of the concentrations of $\mathrm{YE}$ and $\mathrm{SC}$ on microbial transglutaminase production obtained at $96 \mathrm{~h}$ of fermentation is shown. The model predicts a maximum activity of $1.074 \mathrm{U} / \mathrm{mL}$ using $10 \mathrm{~g} / \mathrm{L}$ of YE, $2 \mathrm{~g} / \mathrm{L}$ of CSL and $13.7 \mathrm{~g} / \mathrm{L}$ of SC supplementing the potato hydrolysates.

A set of four confirmation experiments was performed to verify the optimum results obtained. The results gave an average of $1.128 \pm 0.10 \mathrm{U} / \mathrm{mL}$.

\section{Discussion}

These results are very good compared with those obtained using other agricultural wastes as fermentation media. For example, by using hydrolysates of sorghum straw, up to $0.348 \mathrm{U} / \mathrm{mL}$ of MTG was obtained (Tellez-Luis, 
Gonzalez-Cabriales, Ramirez, \& Vazquez, 2004). Using sugar cane molasses with glycerol, up to $0.460 \mathrm{U} / \mathrm{mL}$ of MTG was obtained (Portilla-Rivera et al., 2009). Using glycerol alone as carbon source, up to $0.725 \mathrm{U} / \mathrm{mL}$ of MTG was obtained (Tellez-Luis et al., 2004).

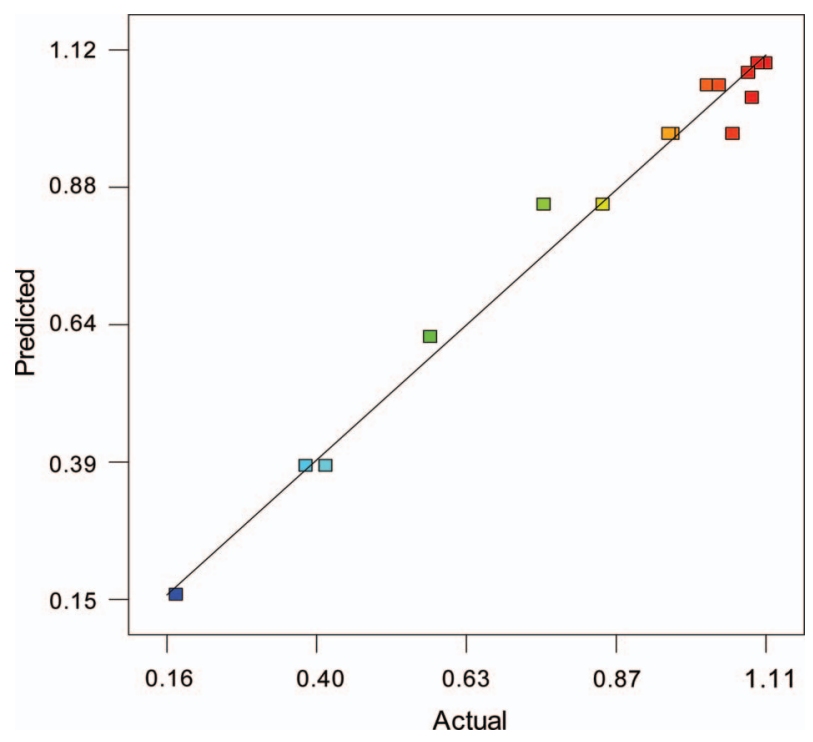

Figure 3. Predicted values vs. actual values (experimental data) for the model $\mathrm{TG}_{96}(\mathrm{U} / \mathrm{mL})$.

Figura 3. Valores predichos contra reales (datos experimentales) para el modelo $\mathrm{TG}_{96}(\mathrm{U} / \mathrm{mL})$.
Many of these formulations include casein concentrations higher than that optimised for the enzymatic hydrolysates of potato. For example, using sugar cane molasses with glycerol, $38.4 \mathrm{~g} / \mathrm{L}$ was optimised (Portilla-Rivera et al., 2009). Using glycerol as carbon source, $20 \mathrm{~g} / \mathrm{L}$ was obtained as optimum (Tellez-Luis et al., 2004).

The mathematical models obtained for the formulation with enzymatic hydrolysates of potato showed a significant effect of YE and SC, the effect of CSL being non-significant. This implies that CSL is needed, but in the range of study the differences in transglutaminase activity are not due to the effect of the level of CSL.

From a technical point of view, the conditions to allow the highest transglutaminase activity per $\mathrm{ml}$ could be considered the target of the optimisation process. However, economic aspects should be also considered. In order to provide a better optimisation of the process, a new variable can be defined to measure the economical combined effect of medium composition: the economic yield of transglutaminase (EY). The EY was defined as monetary units (euros) of transglutaminase produced per monetary unit (euros) spent in nutrients. This is an important parameter for evaluating the technical and economical performance of the process.

From material balances, it can be inferred that EY depends on transglutaminase activity obtained (U/L) according to the following equations:

$$
\mathrm{EY}=\frac{Y}{\sum(C \cdot N)} I
$$

where $C$ is the cost of each nutrient $(€ / \mathrm{g}), I$ is the selling price of transglutaminase $(€ / \mathrm{U})$ and $N$ is each nutrient

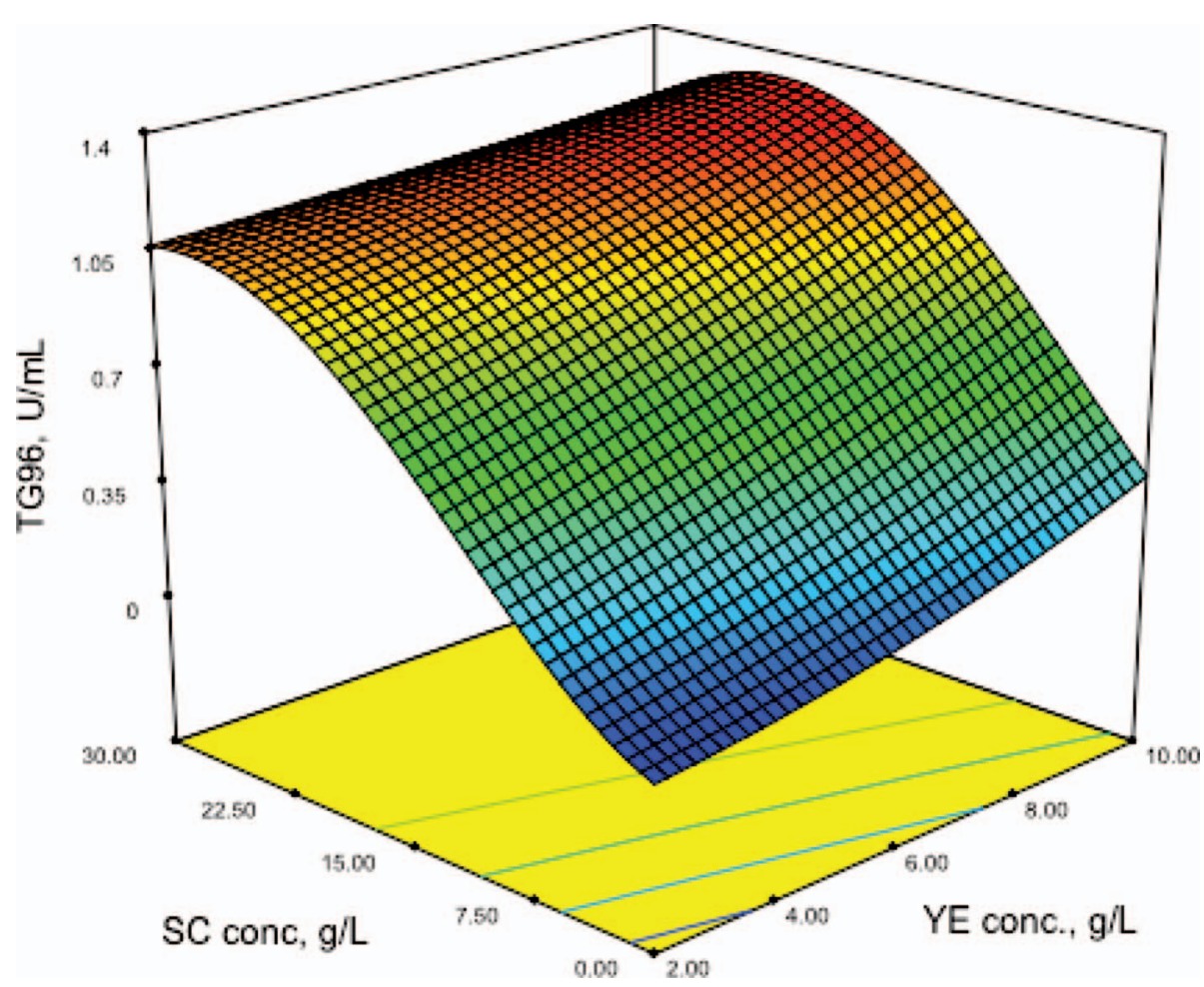

Figure 4. Prediction of the model for transglutaminase activity $(\mathrm{U} / \mathrm{mL})$ obtained in the fermentation at $96 \mathrm{~h}\left(\mathrm{TG}_{96}\right)$ on sodium caseinate $(\mathrm{SC})$ and yeast extract (YE), both in $\mathrm{g} / \mathrm{L}$.

Figura 4. Predicción del modelo para actividad transglutaminásica $(\mathrm{U} / \mathrm{mL})$ obtenidas en la fermentación a 96 h ( $\left.\mathrm{TG}_{96}\right)$ en función del caseinato de sodio (SC) y extract de levadura (YE), ambas en $\mathrm{g} / \mathrm{L}$. 


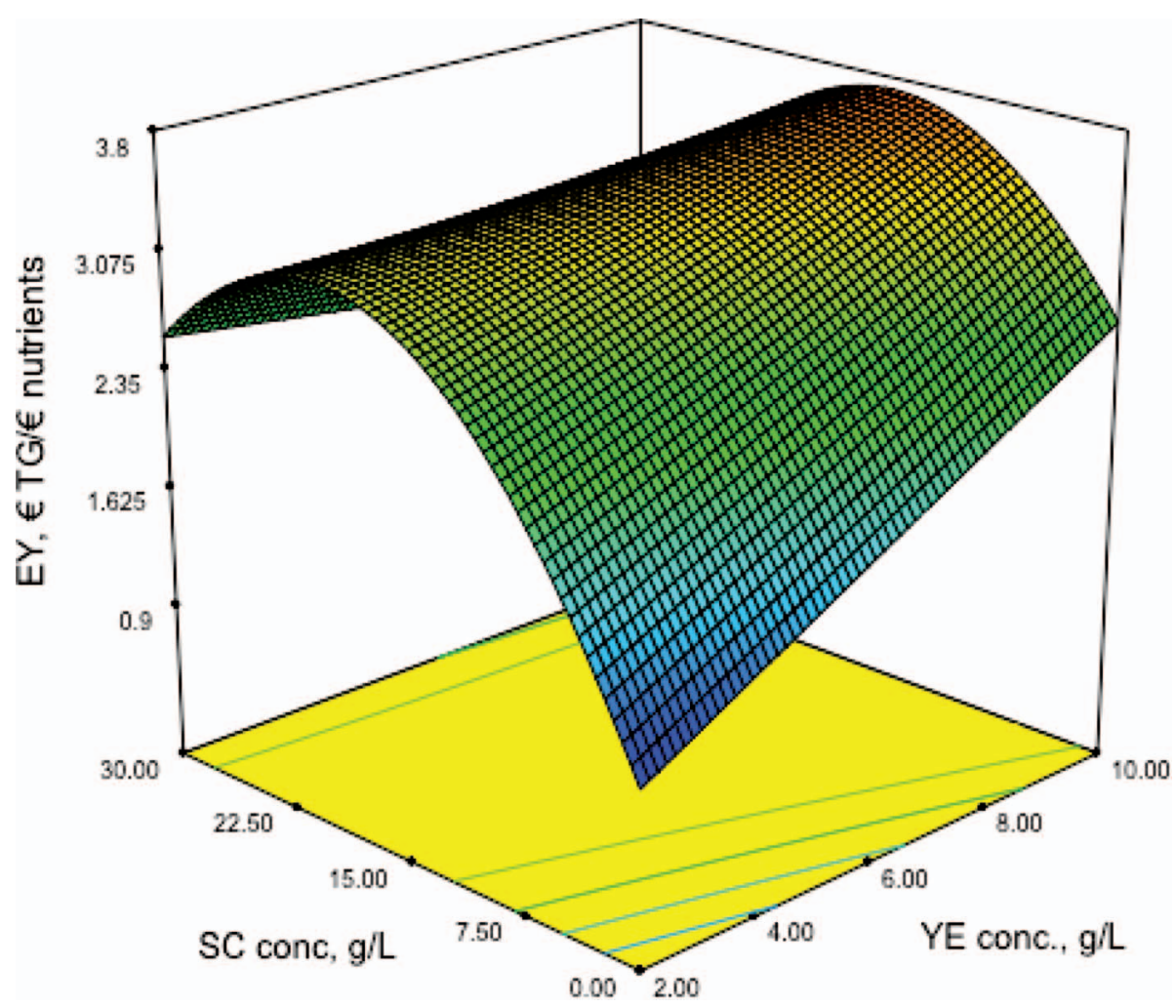

Figure 5. Prediction of the model for economic yield of transglutaminase EY $(€ / €)$ obtained in the fermentation at $96 \mathrm{~h}\left(\mathrm{TG}_{96}\right)$ on sodium caseinate (SC) and yeast extract (YE), both in $\mathrm{g} / \mathrm{L}$.

Figura 5. Predicción del modelo para el rendimiento económico de transglutaminasa EY $(€ / €)$ obtenidas en la fermentación a 96 h $\left(\mathrm{TG}_{96}\right)$ en función del caseinato de sodio (SC) y extract de levadura (YE), ambas en $\mathrm{g} / \mathrm{L}$.

concentration $(\mathrm{g} / \mathrm{L})$ and $Y$ is the transglutaminase activity $(\mathrm{U} / \mathrm{L})$. The dependence of economic yield on the medium composition can be predicted from the empirical model and equation above. For calculation purposes, the cost of each nutrient was fixed in values previously reported: CSL, $0.4 € / \mathrm{kg}$; YE, $8.5 € / \mathrm{Kg}$; SC, $8.5 € / \mathrm{kg}$ (Bustos et al., 2004). The selling price of transglutaminase $(0.00065 € / \mathrm{U})$ was inferred from the market value showed in the website of a producer (https://www.e-shoponline.es/epages/eb4607.sf/es_ $\mathrm{ES} /$ ?ViewObjectID=247497) where $65.61 € / \mathrm{kg}$ is the price of a product containing $100 \mathrm{U} / \mathrm{g}$.

The values obtained of EY showed that the cost of the nutrients is lower than the income obtained from the transglutaminase generated with values of EY in the range $1.005-4.002 € / €$. The model obtained for the transglutaminase activity can be optimised to obtain the maximum economic yield. The composition of medium for the maximum economic yield was similar than for the maximum transglutaminase activity as can be seen in Figure 5 .

Therefore, taking into account of these considerations, the technical and economical optimisation gave the following optimal conditions: $10 \mathrm{~g} / \mathrm{L}$ of YE, $2 \mathrm{~g} / \mathrm{L}$ of CSL and $13.7 \mathrm{~g} / \mathrm{L}$ of SC. Using enzymatic hydrolysates of potato with this nutrient supplementation, a maximum activity of $1.128 \pm$ $0.10 \mathrm{U} / \mathrm{mL}$ was obtained with a maximum economic yield of $3.72 €$ (obtained selling transglutaminase) per each $€$ spent in nutrients. To conclude, the enzymatic hydrolysates of potato supplemented with YE, CSL and SC were feasible media for the production of transglutaminase by S. mobaraensis.

\section{Acknowledgements}

The authors are grateful to Ministerio de Educación y Ciencia (Spain) for the financial support of this work (Project: AGL2006-08250/ALI) and the FEDER funds of the European Union.

\section{References}

Ando, H., Adachi, M., Umeda, K., Matsuura, A., \& Nonaka, M. (1989). Purification and characteristics of a novel transglutaminase derived from microorganisms. Agricultural and Biological Chemistry, 53, 2613-2617.

Bahrim, G., Iancu, C., Butu, N., \& Negoita, T. (2010). Production of a novel microbial transglutaminase using Streptomyces Sp. Polar Strains. Romanian Biotechnology Letters, 15, 5197-5203.

Beninati, S., \& Piacentini, M. (2004). The transglutaminase family: An overview: Minireview article. Amino acids, 26, 367-372.

Bonato, P., Perlo, F., Teira, G., Fabre, R., \& Kueider, S. (2006). Nuggets with washed mechanically deboned chicken meat: Frozen storage stability. Ciencia y Tecnologia Alimentaria, 5, 112-117.

Box, G., \& Behnken, D. (1960). Some new three level designs for the study of quantitative variables. Technometrics, 2, 455-475.

Bustos, G., Moldes, A.B., Alonso, J.L., \& Vazquez, M. (2004). Optimization of D-lactic acid production by Lactobacillus Coryniformis using response surface methodology. Food Microbiology, 21, 143-148.

Castro-Briones, M., Calderon, G.N., Velazquez, G., Rubio, M.S., Vazquez, M., \& Ramirez, J.A. (2009). Mechanical and functional properties of beef products obtained using microbial transglutaminase with treatments of pre-heating followed by cold binding. Meat Science, 83, 229-238.

Ce, N., Norena, C.P.Z., \& Brandelli, A. (2012). Antimicrobial activity of chitosan films containing nisin, peptide P34, and natamycin. CyTA - Journal of Food, 10(1), 21-26. 
Delgado, R., Castro, A.J., \& Vazquez, M. (2009). A kinetic assessment of the enzymatic hydrolysis of potato (Solanum tuberosum). Food Science Technology, 42, 797-804.

Dube, M., Schaefer, C., Neidhart, S., \& Carle, R. (2007) Texturisation and modification of vegetable proteins for food applications using microbial transglutaminase. European Food Research and Technology, 225, 287-299.

Grossowicz, N., Wainfan, E., Borek, E., \& Waelsch, H. (1950). The enzymatic formation of hydroxamic acids from glutamine and asparagine. Journal of Biological Chemistry, 187(1), 111-125.

Guerra-Rodriguez, E., Portilla-Rivera, O.M., Jarquin-Enriquez, L., Ramirez, J.A., \& Vazquez, M. (2012). Acid hydrolysis of wheat straw: A kinetic study. Biomass \& Bioenergy, 36, 346-355.

Junqua, M., Duran, R., Gancet, C., \& Goulas, P. (1997). Optimization of microbial transglutaminase production using experimental designs. Applied Microbiology and Biotechnology, 48, 730-734.

Montouto-Grana, M., Vazquez-Oderiz, M.L., Romero-Rodriguez, M.A., \& Munoz-Ferreiro, N. (2012). Influence of storage conditions on the sensory and physicochemical characteristics of Galician Kennebec potatoes (Solanum Tuberosum L.). CyTAJournal of Food, 10(1), 48-56.

Nagy, V., \& Szakacs, G. (2008). Production of transglutaminase by streptomyces isolates in solid-state fermentation. Letters in Applied Microbiology, 47, 122-127.

Portilla-Rivera, O., Tellez-Luis, S., Ramirez de León, J.A., \& Vazquez, M. (2009). Production of microbial transglutaminase on media made from sugar cane molasses and glycerol. Food Technology and Biotechnology, 47(1), 19-26.

Ramirez, J., Uresti, R., Tellez, S., \& Vazquez, M. (2002). Using salt and microbial transglutaminase as binding agents in restructured fish products resembling hams. Journal of Food Science, 67, $1778-1784$.

Sommer, C., Volk, N., \& Pietzsch, M. (2011). Model based optimization of the fed-batch production of a highly active transglutaminase variant in Escherichia Coli. Protein Expression and Purification, 77(1), 9-19.

Tellez-Luis, S.J., Gonzalez-Cabriales, J.J., Ramirez, J.A., \& Vazquez, M. (2004). Production of transglutaminase by Streptoverticillium ladakanum NRRL-3191 grown on media made from hydrolysates of sorghum straw. Food Technology and Biotechnology, 42(1), 1-4.
Tellez-Luis, S.J., Moldes, A.B., Vazquez, M., \& Alonso, J.L. (2003). Alternative media for lactic acid production by Lactobacillus delbrueckii NRRL b-445. Food and Bioproducts Processing, 81(C3), 250-256.

Tellez-Luis, S.J., Ramirez, J.A., \& Vazquez, M. (2004). Production of transglutaminase by Streptoverticillium Ladakanum NRRL-3191 using glycerol as carbon source. Food Technology and Biotechnology, 42, 75-81.

Tellez-Luis, S.J., Uresti, R.M., Ramirez, J.A., \& Vazquez, M. (2002). Low-salt restructured fish products using microbial transglutaminase as binding agent. Journal of the Science of Food and Agriculture, 82, 953-959.

Uresti, R.M., Velazquez, G., Ramirez, J.A., Vazquez, M., \& Torres, J.A. (2004). Effect of high-pressure treatments on mechanical and functional properties of restructured products from arrowtooth flounder (Atheresthes Stomias). Journal of the Science of Food and Agriculture, 84, 1741-1749.

Vazquez, M., Delgado, R., \& Castro, A. (2009). Modelling of the enzymatic hydrolysis of potato (Solanum Tuberosum) using response surface methodology. Starch-Starke, 61, 601-609.

Wang, Y., Yu, L., \& Wei, X. (2012). Monosaccharide composition and bioactivity of tea flower polysaccharides obtained by ethanol fractional precipitation and stepwise precipitation. $C y T A-$ Journal of Food, 10(1), 1-4.

Yan, G.L., Du, G.C., Li, Y., Chen, J., \& Zhong, J.J. (2005). Enhancement of microbial transglutaminase production by Streptoverticillium mobaraense: Application of a two-stage agitation speed control strategy. Process Biochemistry, 40, 963-968.

Zeni, J., Colet, R., Cence, K., Tiggemann, L., Toniazzo, G., Cansian, R.L., ..., Valduga, E. (2011). Screening of microorganisms for production of carotenoids. CyTA - Journal of Food, 9, $160-166$.

Zhou, L.D., Chen, J., \& Du, G.C. (2000). Functional properties of microbial transglutaminase and its application method in food processing. China Food Addit, 2000(1), 54-59.

Zidani, S., Fahloul, D., \& Bacha, A. (2012). Effects of pH, $\mathrm{NaCl}$, ethanol, and drying methods on the solubility of Saccharomyces cerevisiae proteins. CyTA - Journal of Food, 10(1), 42-47. 